\title{
Masyarakat Adat dan Diskursus Representasi di Lingkar Arktik: Tinjauan Kosmopolitanisme dan Geopolitik Kritis
}

\author{
Andy Fernanda Probotrianto \\ Universitas Airlangga
}

\begin{abstract}
Abstrak
Lingkar Arktik tidak dapat dipungkiri telah menjadi wilayah yang cukup kompleks dan prominen pada era kontemporer; utamanya jika dikaitkan dengan diskursus sumber daya, energi, dan kemaritiman yang kini menjadi kontestasi politik di ranah internasional. Diskursus tersebut semakin terproliferasi semenjak mencairnya es di area kutub. Namun selama ini, paradigma yang diusung dalam kajian Lingkar Arktik berpusat pada perhelatan antar negara dan isu-isu high politics semata dan mengacuhkan adanya aktor lain yang termarjinalkan, seperti peran masyarakat adat (indigenous people). Dengan menggunakan analisis Kosmopolitanisme Kritis sebagai landasan normatif dan menginduksikan pendekatan dari Geopolitik Kritis, tulisan ini hendak berkontribusi pada kajian diskursus perpolitikan di Lingkar Arktik dengan menginklusikan perspektif masyarakat adat, utamanya Suku Inuit sebagai populasi terbesar di wilayah Arktik, dalam memandang dinamika kawasan dan mendekonstruksi dampak aktor-aktor hegemon di kawasan tersebut. Tulisan ini menemukan bahwa perubahan paradigma global yang semakin mempromosikan nilai-nilai Kosmopolit, seperti inklusivitas, telah memberi jalan bagi representasi dan posisi yang lebih signifikan bagi masyarakat adat.
\end{abstract}

Kata kunci: Lingkar Arktik; Masyarat Adat; Suku Inuit; Hegemoni Nation-States; Representasi

The Arctic Circle, without a doubt, has turned into a region of various complexities and holds a huge prominence in the contemporary world; especially if one link it with discourses regarding energy, resources, and maritime issues which have helped triggering wide international contestations. These discourses are getting more proliferated as the polar ice melts. However, the existing paradigm carried about within the research of the region tends to be ignorant of those whom are marginalized and hidden under the shadows of nation-states and high politics agendas: the indigenous peoples. By utilizing Critical Cosmopolitanism as a normative basis, as well as taking the approach offered by Critical Geopolitics, this writing will try to contribute on the political discourse of Arctic Circle by including the perspectives of Inuit Peoples as the biggest indigenous population of the Arctic in seeing the regional dynamics and deconstructing the impact of hegemonic roles in the region. This article reveals that the shifting global paradigm which, in time, echoing Cosmopolitanism values, such as inclusivity, paves a way to the growing representation to the indigenous peoples.

Keywords: Arctic Circle; Indigenous Peoples; Inuit Peoples; Nation-states Hegemony; Representation 


\section{Pendahuluan}

Dewasa ini, kawasan Lingkar Arktik telah menjadi wilayah yang dipandang semakin signifikan secara geopolitik dan geostrategi. Berbagai literatur memaparkan Artik sebagai sebuah 'frontier' baru yang menunggu untuk dijelajahi (Bruun \& Medby 2014; Doods \& Nuttall 2019b). Apabila ditelusuri dari aspek sumber daya, hal ini tidak mengherankan mengingat wilayah diestimasikan mengandung setidaknya $13 \%$ cadangan minyak bumi (90 triliun kubik barel) dan 30\% gas alam di dunia (1670 triliun kubik kaki) (U.S Geological Survey 2008). Melelehnya lapisan es di daerah kutub lantas semakin membuka jalan bagi adanya eksplorasi dan potensi bagi adanya jalur transportasi laut transkontinental baru. Berbagai negara pun tidak segan-segan memanfaatkan momentum tersebut. Sebagai contoh, pada tahun 2007 silam, Rusia menginisiasi sebuah proyek saintifik yang ditujukan untuk memetakan-dan berpotensi memperluas-landasan kontinennya yang mana berujung pada penanaman bendera yang cukup kontroversial (Doods 2010; Dittmer et. al., 2011). Langkah ini mendapat respon tegas dari berbagai negara, khususnya yang berada di tepi Laut Arktik, dan memunculkan adanya sentimen teritorialisme di kawasan ini.

Berbagai pakar lantas mensinyalir keadaan ini sebagai revivalisme geopolitik klasik. Akan tetapi, posisinya tereformulasi dalam konteks kontemporer. Sebagaimana yang dituliskan oleh Doods \& Nuttall (2019b) persepsi lama yang menyatakan bahwa Artik hanya sebatas 'icy wasteland' dengan adanya berbagai unsur yang kini membuat fenomena yang terjadi di kawasan ini semakin kompleks, seperti globalisasi, teknologi, perubahan iklim, dan lain sebagainya. Beragam kepentingan baru, baik secara politik, komersil, maupun saintifik pun terploriferasi dan diasosiasikan pula dengan kawasan ini (Ebinger \& Zambetaki, 2009). Hal tersebut menjadikan preskripsi Mackinderian yang memproposisikan nilai penting dari 'Pivot Area' dan 'Heartland' sebagai objek geostrategi kini menjadi kurang relevan. Kontestasi politik kini bergeser pada wilayah yang selama ini terkesan dinomorduakan. Secara singkat, permasalahan mengenai geopolitik yang terdapat di wilayah Arktik menandakan sebuah titik balik baru dalam diskursus geopolitik kontemporer.

Akan tetapi, terdapat pula sejumlah literatur yang menilai bahwa cara pandang yang state-centric dan fokus pada high politics ini cenderung menutupi aspek-aspek sosio-politik yang tidak kalah penting untuk disorot. Perspektif ini secara tidak langsung menafikan unsur-unsur lain yang tidak kalah penting, seperti mencairnya es yang diasosiasikan dengan global warming (Depledge \& Kennedy-Pipe 2018) dan kurang 
diperhatikannya ramifikasi terhadap ekosistem, habitat, dan satwa liarseperti Beruang Kutub dan Paus-serta sekor-sektor lingkungan lainnya (Hommel \& Murphy 2013). Meskipun terdapat berbagai pembahasan kritis yang disajikan, muncul skeptisisme bahwa hal ini justru akan membawa bias tersendiri bagi indigenous people atau masyarakat adat yang tinggal di kawasan Artik. Sebagaimana yang disinggung oleh Doods dan Nuttall (2019a; 2019b), perspektif ini dinilai terlalu menyudutkan posisi dan meminimalisir keterlibatan masyarakat adat dalam perhelatan geopolitik Artik. Dalam geopolitik territorial dan sumber daya, keberadaannya tertutupi oleh interaksi antar nation-states. Hal yang sama dialami konteks geopolitik lingungan di mana masyarakat adat dinilai turut bertanggung jawab atas eksploitasi satwa dan ekosistem dalam bentuk aktivitas perburuan dan whaling atau perburuan paus.

Tulisan ini lantas berkontribusi pada kajian diskursus perpolitikan di Lingkar Arktik dengan menginklusikan perspektif masyarakat adat dalam memandang dinamika geopolitik yang terjadi di kawasan tersebut. Mengingat dinamika demografis masyarakat adat Lingkar Arktik yang juga cukup kompleks (Doods \& Nuttal 2019b), tulisan ini lebih menekankan fokus kajian pada Suku Inuit sebagai salah satu masyarakat adat yang terbesar dan terprominen-bersamaan dengan Suku Saami (Plaut, 2012). Dengan mengutilisasikan Paradigma Kritis dalam Kosmopolitanisme (Delanty 2008;2014; Uimonen 2020) dan Geopolitik (O Tuathail 1999; Flint 2006)-beserta turunan terkaitnya, seperti Kosmopolitanisme Poskolonial (Go, 2012) dan Indigenous Geopolitics (Gibson, 2016), tulisan ini akan menelusuri bagaimana emergensi sosio-politik masyarakat adat yang dimanifestasikan dari koridor self-representation di tingkat bawah atau grassroot hingga terintegrasi dalam Global Governance-yang membuatnya dapat bersandingan dengan nation-states. Dalam menjelaskan hal-hal tersebut, tulisan ini dimulai dengan menjelaskan Kosmopolitanisme Poskolonial dan Geopolitik Kritis sebagai kerangka teoritis. Selanjutnya, pemaparan kedudukan sosial, politik, dan budaya dari masyarakat adat dan Suku Inuit, beserta masalah representasi yang kerap kali ditemui. Pola emergensinya, utamanya dalam hal emansipasi dan aktivisme politik, kemudian dianalsis dengan menggunakan kedua pendekatan yang telah disebutkan. Tulisan ini diakhiri dengan kesimpulan mengenai bagaimana prospek dari representasi masyarakat adat, khususnya Suku Inuit, dalam kontestasi perpolitikan Lingkar Arktik.

\title{
Kerangka Teoritis dalam Memandang Lingkar Arktik
}

\author{
Kosmopolitanisme Kritis dan Kosmopolitanisme Poskolonial
}


Pembahasan mengenai Paradigma Kosmopolitanisme diberbagai disiplin ilmu sosial-termasuk inkoporasinya dalam Studi Internasionaltelah membawakan berbagai postulasi normatif dalam diskursus kajiannya. Akan tetapi, normativitas tersebut jauh lebih spesifik dan praktis-jika dibandingkan dengan Kosmopolitanisme Utopis yang dikenalkan oleh pemikiran Stoic. Berbagai literatur, seperti Paula Uimonen (2020) menuliskan bahwa para akademisi Kosmopolit Kontemporer acapkali merujuk pada karya Kosmopolitanisme yang diformulasikan oleh Immanuel Kant. Karya-karya fenomenalnya, seperti Perpetual Peace, menggariskan nilai-nilai universalitas Kosmopolitanisme yang berbasis pada persamaan hak, humanisme, dan penakanan baru seperti World Citizenship dan World Society. Prinsip-prinsip keramahan atau hospitality yang dituangkannya juga menyoroti aspek keadilan dan kesejahteraan yang dinilainya harus diterapkan melampaui batas-batas lokalitas (Go, 2012; Delanty, 2014). Pandangan ini lantas digunakan oleh berbagai ahli, seperti David Held dan Martha Nussbaum (dalam Delanty, 2008) dan untuk menerjemahkan berbagai persoalan yang berkaitan dengan kesadaran dan solidaritas global, serta Transnasionalisme.

Namun, analisis ontologis yang dilakukan oleh Mignolo (2000, dalam Uiomen 2020) menemukan bahwa postulasi Kantian mengandung bias tersendiri yaitu posisi Eurocentric yang mempersepsikan diri sebagai peradaban yang paling beradab di dunia. Lantas, Universalisme, Keadilan dan Kesejahteraan yang dibawakannya tidak dikonsiderasikan dengan variasi dan kompleksitas yang terdapat pada realitas yang ada, sehingga cenderung mendukung agenda homogenisasi barat alih-alih agenda emansipatif. Meski kosmopolitanisme secara umum telah memberikan kerangka normatif yang dapat digunakan untuk menganalisis pergerakan yang terjadi di belahan dunia lain, Delanty (2014) menilai genealogis Barat yang dikandungnya membuat relevansi global yang dibawakannya menjadi terbatas. Dalam konteks Lingkar Arktik, perspektif masyarakat adat dalam tata-kelola Arktik tidak sepenuhnya diakomodir dalam kerangka ini. Kedudukannya cenderung dinomorduakan, bahkan diantagonisasikan dalam diskursus Kosmopolit lain yang dinilai memiliki implikasi global yang lebih luas, seperti masalah ekologis dan perubahan iklim di mana masyarakat adat diklaim turut bertanggungjawab (Doods \& Nuttall, 2019b).

Lantas, sebuah pendekatan Kosmopolitanisme yang lebih inklusif pun diperlukan untuk melihat secara komprehensif mengenai sejauh mana distingsi dari cara pandang masyarakat adat mempengaruhi perhelatan politik di Lingkar Arktik. Gerard Delanty (2008) pun memperkenalkan 
paradigma Kosmopolitanisme Kritis yang mengkritisi keterbatasan pemikiran Kosmopolitanisme Kantian yang menggaungkan filsafat moral dan politik Barat yang berorientasi pada terbentuknya tatanan world community yang universal, namun dalam pemaknaan yang bersifat one-dimensional. Lebih spesifik, konteks historis dari kedudukan Suku Inuit sendiri juga dapat direfleksikan dalam kajian turunannya, yakni Kosmopolitanisme Poskolonial yang dielaborasikan oleh Franz Fanon (dalam Go, 2012). Pemikiran ini menyoroti bahwa perjalanan Kosmopolitanisme perlu disoroti dari segi sejarah, yang mana universalisme Kantian diperkenalkan secara bias pada era kolonialisme. Meskipun secara intrinsik Kosmopolitanisme sudah mengandung unsur kritis, kehadiran gelombang Kritis ini ditujukan untuk mereformulasi universalisme Kosmopolitanimse dengan unsur 'intersubjektifitas' melalui inklusi konteks-konteks kultural dan melihat dari sudut pandang lokal dan global di saat yang bersamaan (Go, 2012; Delanty, 2014). Dengan demikian, diharapkan dapat dihasilkan suatu pemahaman Kosmopolit yang reflektif terhadap efek transformatif yang dihasilkan sebagai dampak dari perhelatan global (Delanty, 2008).

\section{Geopolitik Krisis dan Indigenous Geopolitics}

Kosmopolitanisme Kritis dan Poskolonialisme yang menyajikan landasan normatif yang dapat digunakan untuk mengkaji dinamika pergerakan emansipatif dari kelompok yang termarginalisasi oleh hegemoni barat maupun terbayang-bayangi oleh narasi Kolonialisme, layaknya komunitas masyarakat adat. Namun, Kosmopolitanisme sendiri tidaklah cukup untuk memaparkan secara komprehensif dinamika yang terjadi di Lingkar Arktik. Kritik seperti Timothy Brennan (1997) menilai bahwa normativitas Kosmopolitanisme membuat sejumlah konsepnya tidak terdefinisikan dengan baik dan kurang dikembangkan secara empiris. Untuk mengisi kekosongan tersebut, maka tulisan ini juga akan mengutilisasikan pendekatan Geopolitik, sebagaimana diskursus mengenai Lingkar Arktik acapkali diploriferasi dalam koridor ini pula. Definisi yang dikemukakan oleh Collin Flint (2006) telah merepresentasikan maksud dari kajian ini ketika mengatakan bahwa geopolitik adalah sebuah situated knowledge yang mana geopolitik merupakan persepsi manusia terhadap ruang dan lingkungan yang ada disekitarnya. Hal ini diimajinasikan dan cenderung dipersepsikan secara inter-subjektif oleh suatu komunitas. Dalam konteks Lingkar Artik, dapat dikatakan bahwa geopolitik adalah konsep yang merepresentasikan persepsi-persepsi dari para aktor yang terlibat dalam perhelatan di kawasan tersebut mulai dari nation-states, rezim-rezim internasional, hingga masyarakat adat. 
Pada awalnya Geopolitik adalah kajian yang bersifat preskriptif. Kedudukannya acapkali tidak terpisahkan dari proses statecraft. Analisis yang dikemukakan oleh para pemikir geopolitik Klasik seperti Ratzel, Mackinder, Mahan dan Spykman (dalam Cohen 2015) cenderung mengutilisasikan geopolitik untuk agenda-agenda yang bersifat teritorial, state-centric, dan high politics. Korelasi kontemporer dalam konteks Lingkar Arktik dapat ditemukan pada orientasi kebijakan negara-negara besar, seperti Russia yang kini memiliterisasi perairan utara-nya (Doods 2010) maupun pertentangan yang kini dikemukakan oleh Amerika Serikat dalam doktrin Mare Liberum atau Common of the Sea yang mendorong terciptanya perairan Arktik yang lebih bebas bagi semua untuk bernavigasi (Brunn \& Medby 2014). Pendekatan Geopolitik ini lantas dikritik karena postulasinya yang terlalu state-centric, dangkal dan terlalu geo-determinist, sehingga egoistik karena hanya memproyeksikan geopolitik secara bias terhadap satu sudut asumsi politik dan budaya tertentu semata (O Tuathail 1999). Dalam konteks Lingkar Arktik, persepsi masyarakat Adat terhadap lingkungan Arktik lantas tertutupi oleh persepsi-persepsi serta preskripsi praktis dari Geopolitik Sumber Daya yang kini prominen di antara nation-states.

Lantas sebuah paradigma Kritis pun dikenalkan dalam kajian Geopolitik untuk memahami bagaimana aktor-aktor yang selama ini termarjinalkan, seperti masyarakat adat, mempersepsikan lingungannya. Meski tidak memberikan postulasi maupun preskripsi yang benar-benar konkrit layaknya Geopolitik Klasik, Dalby (2006) menilai bahwa pemikiran ini secara metodologis membukakan jalan bagi analisis dengan pendekatan yang non-positivis. Geopolitik Kritis menekankan skeptisime terhadap preskripsi one-dimensional dari paradigma Klasik dengan adanya penolakannya terhadap unsur 'netralitas' dalam politik. O Tuathail (1999) memberikan sejumlah argumen yang dapat digunakan digunakan dalam analisis kritis yaitu dekonstruksi terhadap unsur-unsur hegemonik dan identifikasi relasi kuasa antar aktor yang terjadi dalam suatu diskursus.

Dengan demikian, sejumlah unsur yang berpengaruh terhadap masyarakat adat pun dapat diidentifikasi. Lebih spesifik, Indigenous Geopolitics, sebagai turunan dari Geopolitik Kritis, yang digagas oleh Chris Gibson (2016) dapat digunakan untuk mengidentifikasikan bagaimana masyarakat adat mempersepsikan lingkungannya. Pendekatan ini menggarisbawahi masyarakat adat sebagai agen utama dalam perhelatan geopolitik dan bagaimana aktor tersebut memposisikan diri dalam sejumlah diskursus. Umumnya, diskursus berkaitan dengan indigenous sovereignty dan self-determinism adat, legasi adat dan hak terhadap 
tanah, serta pengelolaan sumber daya dan manajemen teritorial-yang diatur dalam koridor internasional.

\section{Aktor Lain di Lingkar Arktik: Masyarakat Adat dan Suku Inuit}

\section{Sekilas Mengenai Masyarakat Adat dan Suku Inuit}

Selain nation-states atau negara-bangsa, masyarakat adat adalah aktor geopolitik lain di Lingkar Artik yang tidak kalah kompleks. Variasi dari masyarakat sendiri cukup beragam dalam koridor kawasan ini. Terdapat sekitar 40 kelompok etnis adat yang berbeda dan tersebar di seluruh penjuru Lingkar Arktik, yang mana berkontribusi pada $10 \%$ total populasi yang ada di wilayah tersebut. Di antaranya, terdapat suku Saami yang bermungkim di wilayah Skandinavia dan Rusia Barat Daya; Nenet, Khant Evenk dan Chuchi di Russia; Aleut, Yupik dan pada akhirnya Inuit yang berada di Alaska dan Kanada (Arctic Centre t.t.). Keberadaan mereka dapat dilacak jauh sebelum adanya kontak dengan masyarakat Barat atau Eropa. Masyarakat Inuit sendiri diketahui sebagai keturunan dari etnis Thule yang menetap di daerah Alaska semenjak tahun 1000 sebelum masehi. Kelompok adat yang secara tradisional merupakan komunitas nomadik ini kemudian bermigrasi dan menetap di daerah Artik lain seperti Kanada dan Greenland (Sowa, 2014). Lantas, komunitas ini pun terbagi kembali menjadi berbagai sub-kultur; dengan Iñupiat di Alaska, Inuvialuit di Kanada, dan Kalaallit di Greenland (Arctic Centre t.t.).

Dinamika demografis masyarakat adat Lingkar Artik berjalan beriringan dengan dinamika masyarakat non-adat. Sebagaimana yang dijelaskan oleh Doods dan Nuttall (2019b), gelombang migrasi dan pergerakan penduduk telah membuat komposisi populasi Arktik semakin beragam. Para pekerja asing berdatangan dari berbagai belahan dunia dan kemudian bekerja untuk industri-industri ekstraktif yang berada di wilayah tersebut. Sehingga, secara sekilas dapat dikatakan bahwa secara empiris komunitas Arktik adalah komunitas yang Kosmopolitan. Hal ini semakin diperkuat dengan kajian geografis Laruelle (2019) mengenai kultur urban kontemporer di Arktik. Masyarakat yang terbentuk kini semakin terdiversifikasi dan terintegrasi secara multikultural. Hal ini dapat diatribusikan pada semangat urbanisme yang menjadi media bagi branding dan semacam cultural showcase atau unjuk kebudayaan bagi para pendatang, serta masyarakat adat yang menetap di daerah kota/urban. Dengan kata lain, permukiman di Lingkar Arktik kini dapat diibaratkan salad-bowl yang penuh dengan keberagaman 
'Situated Knowledge' dari Masyarakat Adat Lingkar Arktik dan Suku Inuit

Sebagaimana yang disorot oleh Brunn \& Medby (2014), persepsi masyarakat adat terhadap Lingkar Arktik sangatlah penting untuk dikaji secara kritis. Hal ini dikarenakan pemukim lokal dan adat memiliki cara mereka sendiri dalam mengkonstruksi pengetahuan, maupun membentuk ontologi komunikasi, bahkan pandangan geografis alternatif yang berbeda dengan aktor-aktor lain, khususnya nation-states yang cenderung mendominasi. Persepsi masyarakat adat ini terbentuk dari interseksi antar unsur filsafat, budaya, dan spiritual yang cukup kompleks. Tanah atau teritori dikonsepsikan dalam terminologi adat Inuit yang disebut sebagai nuna: tempat di mana semua yang 'berada di atas dan di bawah, serta yang ada disekitarnya hidup berdampingan-baik manusia dan mahluk hidup lainnya' (Doods \& Nuttall 2019a). Pemikiran ini pada dasarnya meletakkan posisi kehidupan 'fisikal' dan 'spiritual' sebagai dua aspek yang tidak dapat dipisahkan. Semua mahluk hidup, baik manusia, binatang atau satwa, tumbuh-tumbuhan, dan bahkan mahluk-mahluk 'non-material' dianggap sebagai entitas-tentitas yang saling membaur di dunia ini-atau dalam konteks ini, dunia Arktik (Sowa 2014).

Karena itu, para masyarakat adat dapat dikatakan mencitrakan lingkungan mereka sebagai wilayah yang secara spiritual suci. Kepercayaan Shamanik ini diorientasikan sebagai sistem peringatan agar masyarakat Inuit selalu menjaga dan menghormati lingkungan di sekitar mereka (Doods \& Nuttall 2019a). Hal ini dikarenakan para masyarakat adat ini-dalam segi religiusnya-juga bergantung pada alam. Kepercayaan yang ada seperti adanya entitas Sedna, Dewi Kehidupan Laut, berperan lebih dari sekedar tahayul atau aturan agama, melainkan sebagai cara hidup. Dewi tersebut dan entitas-entitas spiritual lainnya dianggap sebagai 'pemberi rahmat' dan 'perestu' dalam kegiatan perburuan, memancing, atau whaling-yang mana telah menjadi kegiatan tradisional suku Inuit, umumnya yang berada di daerah yang masih kental dengan tradisi (Doods \& Nuttall 2019a). Sehingga, dapat diketahui sebagaimana besarnya signifikansi 'tanah' bagi masyarakat adat, baik secara spiritual dan fungsional; aspek yang menjadi dasar bagi pergerakan kontemporer.

Lebih lanjut, persepsi ini pun dimanifestasikan lebih lanjut dalam ranah tata-kelola masyarakat adat. Suku Inuit memiliki cara pandang epistemologis tersendiri terhadap ekologi Arktik dalam tajuk Inuit Qaujimajatuqangit(IQ)(Brunn\&Medbey 2014). Pemikiraninimengusung berbagai unsur-unsur normatif yang perlu dipenuhi dalam 
pemerintahan adat, seperti 'belajar dari pengalaman; kebaikan dan jasa sebagai sumber dari otoritas; pengambilan kebijakan yang didasari oleh konsensus; menyatu dengan lingkungan sekitar; pengelolaan sumber daya yang diorientasikan untuk kebaikan bersama; serta penghormatan dan toleransi terhadap perbedaan' (Pelaudeix, 2012). Melalui prinsip-prinsip tersebut, masyarakat Inuit dapat menjaga stabilitas dan tatanan secara relatif dalam komunitas. Namun, Brunn \& Medbey (2014) menambahkan bahwa dalam konteks kontemporer, nilai-nilai tersebut tidaklah dipercaya secara kaku. Dengan masuknya pemahaman baru dalam tata-kelola pemerintahan, prinsip ini dapat berjalan beriringan dengan sistem modern-layaknya yang diasersikan oleh negara-bangsa.

\section{Masalah Representasi dan Keadilan di Bawah Bayang-bayang Nation-states}

Pada kenyataannya prinsip-prinsip adat dan modernitas tidak selalu berjalan beriringan. Suku Inuit dan masyarakat adat lainnya acapkali distigmakan sebagai kelompok yang terpisah dari modernitas. Doods dan Nuttall (2019a) memperingatkan akan pentingnya melepaskan diri dari berbagai stereotip yang berkembang seputar masyarakat adatmengingat kompleksitas sosiologisnya yang hampir sama dengan komunitas non-adat. Sejarah dan analisis antropologis memang menunjukan bahwa masyarakat adat Lingkar Arktik pada dasarnya memiliki tradisi berburu dan whaling dalam artian yang tradisional (Brunn \& Medby 2014). Hal ini pun masih dipraktikkan di daerah rural. Akan tetapi, pelabelan ini menafikan variasi, yang mana terdapat pula masyarakat Adat yang juga terpapar oleh kebudayaan urban ataupun variasi lain dari masyarakat adat lainnnya (Doods \& Nutall 2019a). Sebagai akibatnya, masyarakat adat pun dipersepsikan sebagai kelompok yang tidak berkembang dan terbelakang, dalam beberapa hal; lantas mendegradasi signifikansi dan presensi dari masyarakat adat, serta peranannya dalam membentuk dinamika Artik (Pelaudeix 2012).

Permasalahan ini tidakterlepas dari sejarah kolonialisme di Lingkar Arktik. Sebagaimana yang dijelaskan oleh Bloom (1993, dalam Brunn \& Medby 2014) dan Dittmer, et. al. (2011) dengan terminologi gender, lingkungan Arktik telah dipersepsikan masyarakat Barat dan Eropa bak daerah baru yang belum terpetakan dan masih 'perawan'. Hal ini menjadi kesempatan tersendiri bagi masyarakat 'beradab' untuk 'menaklukan'-dalam persepsi yang maskulin-dan 'melindungi' wilayah yang dikesankan rentan dan lemah tersebut-dalam artian feminin. Lebih lanjut, elaborasi Pelaudeix (2012) mencitrakan secara komprehensif bagaimana sentimen negatif terhadap suku Inuit telah berlangsung semenjak terciptanya 'kontak' pertama kali dengan peradaban barat. Hubungan yang terbentuk 
dari barter dan perdagangan ini berujung pada monopoli, utamanya di Alaska dan Kanada pada tahun 1890an. Menurut catatan Alfred Hopson (1970 dalam Pelaudeix 2012), para penduduk kolonial Amerika melakukan perampasan terhadap tanah-tanah kesukuan Inuit. Sebagai konsekuensinya, masyarakat Inuit dilucuti dari hampir segala kapabilitas yang dimilikinya, utamanya ekonomi-membuat komunitas ini menjadi dependen-serta dalam posisi yang periferal-terhadap perekonomian pemukim Barat di Benua Amerika. Hal yang sama juga dirasakan oleh para penduduk Inuit di Greenland semenjak 1925, dibawah bayang-bayang Norwegia dan Denmark Para 'pendatang' ini juga mengeksploitasi sumber daya mineral dan gas alam yang ada di tanah-tanah rampasan tersebut. Tidak hanya itu, bibit-bibit penyakit yang dibawa oleh masyarakat Barat pun juga memiliki implikasi yang tidak kalah pelik terhadap komunitas indigenous tersebut (Pelaudeix 2012).

Pelaudeix (2012) dan Doods \& Nutall (2019a) juga menggarisbawahi adanya persekusi di era kontemporer, utamanya terhadap komunitas urban Arktik, masyarakat adat acapkali mengalami degradasi kultural akibat masuknya arus modernisme tersebut. Kebudayaan adat yang dinilai tidak beradab dipaksa untuk ditinggalkan dan orang-orang indigenous dipaksa untuk meninggalkan kebudayaan aslinya. Dalam konteks orangorang Inuit, sejumlah komunitas dan institusi pendidikan di Kanada dan Greenland-dalam hal ini Denmark-sempat melarang penuturan bahasa kesukuan dan ekspresi kultural adat. Mereka dipaksa untuk berasimilasi dengan gaya hidup modern dan kebarat-baratan (Pelaudeix 2012; Plaut 2012; Doods \& Nuttall 2019a). Hal ini lantas menjadi ancaman tersendiri bagi eksitensi identitas adat dan kesukuan. Sentimen ini pun semakin terlihat dalam konteks budaya populer. Representasi stereotipikal terhadap masyarakat adat selama ini digaungkan oleh masyarakat Eropa melalui media, seperti perfilman. Doods \& Nuttall (2019a) mencontohkan ini dalam film dokumenter yang disutradarai oleh Robert J. Flaherty pada tahun 1922 yang berjudul Nanook of the North; sebuah penggambaran artistik masyarakat adat Arktik sebagai komunitas yang 'eksotis' dan 'terasing'.

Karena itu, salah satu isu yang diangat oleh masyarakat adat adalah mengenai land-rights dan manajemen sumber daya yang masih menjadi permasalahan tersendiri, bahkan di era kontemporer. Menggaungkan kembali mengenai migrasi, keadaan yang dirasakan masyarakat adat, atau Inuit secara spesifik, tidak selalu Kosmopolit dalam pemaknaan yang dijelaskan oleh Laruelle (2019). Gelombang migrasi yang deras pada era kolonial membuat masyarakat adat sempat menjadi kelompok minoritas yang termarginalkan (Pelaudeix 2012). 
Secara ironis, migrasi yang dilakukan oleh masyarakat adat-melintasi jalur nomaden tradisional-acapkali dihalangi dengan adanya batasbatas yang didirikan oleh negara bangsa (Plaut, 2012). Namun, Brunn dan Medby (2014) memperingatkan bahwa agenda self-determinism ini memiliki intensitas yang berbeda-beda, mengingat diversitas demografi dari masyarakat adat itu sendiri. Terdapat pihak yang hanya meminta hak otonomi yang lebih luas; namun juga terdapat pula yang mewacanakan kemerdekaan utuh. Terlepas dari perbedaan tersebut, orientasi yang dimiliki oleh masyarakat secara umum sama yaitu memiliki kendali tersendiri terhadap 'Arctic Homelands' dan bagaimana pengetahuan dan perspesi indigenous dapat diinkorporasikan dalam tata-kelolanya (Doods \& Nuttall 2019a).

Permasalahan mengenai tanah dan manajemen sumber daya ini lantas tidak bisa dipisahkan dengan konsiderasi masyarakat adat terhadap lingkungan. Sebagaimana yang dijelaskan sebelumnya, persepsi geopolitik masyarakat adat terhadap lingkungan Arktik tidak dapat dilepaskan dari segi spiritualismenya. Selain itu, secara fungsional, 'tanah' kesukuan di Arktik telah lama digunakan sebagai lahan perburuan dan pemukiman (Sowa 2014; Doods \& Nuttall 2019a). Lantas, permasalahan yang berkaitan dengan perubahan iklim menjadi salah satu isu yang hendak ditangkal oleh masyarakat adat. Kendati terdapat sejumlah segmen dari masyarakat adat, utamanya yang terjun dalam dunia modern dan industri, yang diuntungkan dengan perubahan iklim (Brunn \& Medbey 2014), hal ini secara umum adalah persoalan yang integral dalam diskursus identitas kesukuan adat Lingkar Arktik (Dittmer, et. al. 2011). Meskipun demikian, posisi masyarakat adat kini juga didudukan dalam posisi antagonis yang sama dengan aktor-aktor komersil, khususnya dalam hal perburuan dan whaling. Masyarakat adat dinilai bertanggungjawab atas eksploitasi anjing laut, beruang kutub, paus, dan satwa-satwa terancam lainnya (Brunn \& Medbey 2014; Doods \& Nuttall 2019a). Namun, persespsi Eurosentrik dan modern terlalu bias melihat signifikansi aktivitas-aktivitas tersebut bagi masyarakat adat. Orientasi aktivitas cukup minim dibidang komersil, dan lebih kearah aspek fungsional, atau kehidupan sehari-hari, dan spiritual (Doods \& Nuttall 2019a).

\section{Perjalanan Aktivisme dan Pergerakan Representasi Suku Inuit}

\section{Self-Representation dan Unjuk Jati Diri}

Dalam rangka meningkatkan emasipasi terhadap masyarakat adat, sejumlah pergerakan pun dilakukan untuk mengekspresikan identitas 
di tengah panggung dunia yang selama ini tertutupi oleh dominasi high politics Barat dan nation-states. Langkah-langkah ini dapat disebut juga sebagai self-representation atau representasi diri dalam diskursus kultur dan budaya. Salah satu contoh yang nyata adalah bagaimana Suku Inuit mencoba untuk merubah citra masyarakat adat Arktik di dunia perfilman. Doods \& Nuttall (2019a) memaparkan berbagai karya-karya yang ditulis dan disutradarai oleh sutradara berdarah Inuit. Isuma Productions membuat sejumlah film yang melukiskan bagaimana kehidupan sehari-hari dari masyarat Nunavut; Film dari Alethea Arnaquq-Baril memberikan pembelaan terhadap budaya perburuan anjing laut-yang mana selama ini dicerca oleh komunitas peduli lingkungan dan satwa-sebagai hak yang dimiliki oleh masyarakat adat. Selain itu, terdapat pula film yang mencitrakan mengenai kepedulian masyarakat adat terhadap lingkungan, seperti halnya yang disutradarai oleh seorang berkesukuan Greenlandik Pipaluk Knudsen-Ostermann, bersama seorang pembuat film asal Belanda, Jan van der Berg (Doods \& Nuttall 2019a).

Tidak hanya itu, masyarakat adat juga teremansipasi dengan membangun narasi tersendiri dalam aspek geopolitik secara eksplisit. Sebagaimana yang dituliskan oleh Brunn dan Medby (2014), masyarakat adat Arktik telah secara terang-terangan 'menantang' monopoli pengetahuan yang selama ini didominasi oleh peradaban barat dengan melakukan 'pemetaan mandiri' terhadap signifikansi sosio-kultural yang ada di dalam komunitas mereka. Dalam hal kartografi, Brunn dan Medby juga menyorot bagaimana mereka 'mempersepsikan ulang' lingkungan mereka dengan disusunnya sebuah atlas virtual mengenai 'Jalur Pan-Acrtic' di dataran utara Kanada-sebuah pencitraan terhadap jalur perburuan dan transportasi tradisional masyarakat adat (Brunn \& Medby 2014). Narasi baru ini pun juga dibantu oleh adanya faktor eksternal sebagaimana yang dipaparkan oleh Laruelle (2019), perubahan pola kehidupan urban di kota-kota Lingkar Arktik telah menggeser paradigma Eurosentrik yang selama ini mendorong intolernasi. Multikulturalisme yang dibawa secara bersamaan dengan gelombang migrasi dari berbagai penjuru dunia-yang utamanya didorong oleh aspek industri dan peluang ekonomi-telah memberikan wadah bagi masyarakat adat untuk melakukan representasi diri atau self-representation, didengar, dan mendapat tempat dalam ranah sosial dan kultural (Laruelle 2019); demikian turut mengkikis stigmatisasi yang selama ini terjadi.

Lantas, kedudukan masyarakat adat pun semakin teremansipasi. Masyarakat non-adat pun semakin terbuka dan toleran terhadap masyarakat adat. Bahkan, posisinya kini mulai terintegrasi dengan 
peradaban modern tanpa harus melalui proses asimilasi yang memaksa. Dalam hal profesi dan pekerjaan, Doods \& Nuttall (2019a) menyinggung di awal bahwa masyarakat adat kini dapat memiliki pekerjaan layaknya kelompok masyarakat lainnya dan, di saat yang bersamaan, bebas untuk menunjukan identitas kulturalnya. Dittmer, et. al. (2011) mengkonkritkan ini dengan menunjukan ada inklusi masyarakat adat dalam kesatuan aparatur negara. Ranger Kanada, sebuah kesatuan yang memiliki tanggungjawab untuk menjaga kedaulatan di areal 'frontier' dan perbatasan, memasukan sejumlah orang dari suku Inuit dan Metis dalam gugusan tugasnya. Terlepas dari kritik ala realis yang disampaikan oleh Dittmer, et. al yang menduga inisasi ini sebagai langkah untuk semata-mata memanfaatkan pengetahuan lokal yang dimiliki oleh anggota Ranger berdarah adat, maupun intensinya yang justru secara implisit mengafirmasi identitas nasional Kanada dalam masyarakat adat (Dittmer, et. al. 2011), inisasi ini menjadi bukti akan inklusivitas masyarakat adat yang semakin terlihat dan didengungkan.

Inuit Circumpolar Council, Arctic Council, dan Pergerakan Transnasional

Tidak hanya itu, aktivisme politik eksplisit juga menjadi bagian dari strategi pergerakan yang digunakan oleh masyarakat adat Lingkar Arktik. Namun, corak pergerakan yang terjadi di Lingkar Artik cukup berbeda dibandingkan dengan apa yang terjadi di kawasan lain. Plaut (2012) mengatribusikan ini pada kultur demokrasi dan politik partisipatif yang relatif tinggi di Benua Amerika (Kanada) dan Eropa. Hal ini lantas membuat masyarakat adat seperti Inuit dan Saami dapat melakukan aktivisme melalui forum-forum kooperatif governmental, serta mendirikan organisasi-organisasi emansipasi hak-hak masyarakat adat dengan leluasa. Realitas ini cukup kontras dengan keadaan yang terjadi di Amerika Latin dan Amerika Serikat, di mana praktik politik partisipatif relatif lebih rendah; demikian mendorong strategi yang bercorak resistensi dan konfrontatif (Gibson 2016). Selain itu, Plaut (2012) dan sejumlah literatur lain (Pelaudeix 2012; Brunn \& Medby 2014) juga menyinggung adanya penerapan prinsip Inuit Qaujimajatuqangit dalam proses aktivisme ini: Mengingat posisinya yang diuntungkan oleh kultur demokrasi yang ada, masyarakat adat lantas menginkorporsikan diri dengan model pemerintahan Barat; namun disertai dengan penonjolan orientasi kepentingan yang bersifat lokal.

Kesempatan untuk menerapkan prinsip IQ secara utuh muncul pertama, semenjak 'kolonialisasi' oleh nation-states suku Inuit mendapatkan hak otonomi khusus di Alaska melalui perjanjian Alaska Native Claims Settlement Act (ANCSA) di tahun 1971 (Pelaudeix 2012); di Greenland 
dalam wacana Home Rule pada tahun 1979, serta Greenland dengan Perjanjian Quebec (1975) dan Inuvialuit (1985) (Doods \& Nuttal 2019). Hal serupa sayangnya belum terjadi di masyarakat Yupik di Rusia, sebagaimana negara tersebut dinilai masih meletakan kepentingan nasional di atas-alih-alih berimbang-dengan kepentingan adat (Dittmer, et. al. 2011). Tentunya, penegasan indigenous sovereignty di wilayah-wilayah tersebut relatif berbeda mengikuti dinamika nation-states yang menaunginya. Namun, ketiganya cenderung berakhir dalam bayang-bayang yang sama.

Menurut Elaborasi Pelaudeix (2012), Suku Inuit Alaska dibawah ANCSA memang mendapatkan klaim yang diinginkan terhadap tanah kesukuan. Namun, klaim ini dapat diibaratkan sebagai kemenangan semu, sebagaimana kepemilikan dan manajemen tanah tersebut dimiliki oleh korporasi yang menjalankan pipa minyak di Alaska-kendati komunitas masyarakat adat dijamin dengan menjadi shareholder. Hal yang sama juga dirasakan oleh Suku Inuit di Kanada-kendati terdapat penerapan traditional knowledge dalam prosedur parlemen Nunavut-yang hanya mendapat 17\% dari tanah kesukuan yang diklaim, dan bahkan tanpa hak royalti terhadap proses produksi komersil yang terjadi di wilayah tersebut. Situasi di Greenland juga menunjukan kontradiksi yang sama antara kepemilikan dan royalti (Pelaudeix 2012).

Semangat untuk mewujudkan agenda self-determination ala masyarakat adat Artik semakin ditunjukan dengan didirikannya Inuit Circumpolar Council (ICC) pada tahun 1980. Kerangka kerja ini menjadi platform bagi meningkatkan peluang bagi Suku Inuit untuk mewujudkan kepentingankepentingan adat, khususnya dalam aspek perjuangan bagi kepemilikan tanah dan hak self-governing yang lebih luas, sebagaimana organisasi ini membawahi keempat suku Inuit di Alaska, Kanada, Greenland, dan Russia dalam satu identitas 'Inuit' (Plaut, 2012). Langkah ini secara konkrit dimanifestasikan dengan adanya Inuit Declaration on Artic Sovereignty. Sebagaimana yang dijelaskan oleh Doods dan Nutall (2019a) deklarasi ini ditujukan untuk mereafirmasi terhadap pengakuan persepsi masyarakat adat Inuit terhadap 'Arctic Homeland' beserta haknya dalam menata-kelola wilayah tersebut, utamanya dalam dunia yang sekarang digambarkan sedang melakukan 'Scramble for Arctic'-maraknya kontestasi politik yang didasari atas perebutan sumber daya. Semua pihak yang terlibat dalam perhelatan Lingkar Artik-terlebih nation-statesdiharapkan dapat berinteraksi dengan bijak dan melakukan konsiderasi terhadap upaya preservasinya, khususnya dalam diskursus perubahan iklim.

Adanya ICC juga membantu Suku Inuit untuk mencapai bargaining 
power yang lebih tinggi di kancah internasional dan transnasional. Salah satunya adalah Arctic Council (AC) sebagai kerangka kerja regional. Pada awalnya, AC hanya menjadi wadah yang digunakan oleh nation-states untuk berokoordinasi dan membahas sejumlah isu politik yang berkaitan dengan persengketaan, umumnya perkara landasan kontinen yang cukup kontrovesial (Brunn \& Medbey 2014; Dittmer, et. al. 2011). Akan tetapi, seiring berkembangnya waktu, signifikansi masyarakat adat yang kian vokal turut dipertimbangkan-bahkan dalam koridor geopolitik sumber daya yang cenderung bersifat high politics sekalipun. ICC pun menjadi salah satu dari enam lembaga masyarakat adat yang diakui sebagai anggota permanen dalam AC (Doods \& Nuttall 2019a). Selain itu, di Persatuan Bangsa-bangsa (PBB) juga turut menyuarakan aspirasinya dalam koridor norma UN Declaration on the Rights of Indigenous Peoples yang menjamin hak masyarakat adat untuk menentukan nasib sendiri (Pelaudeix 2012) dan dipercaya untuk terlibat dalam forum masyarakat adat yang disediakan-bergantian dengan Saami Council (Plaut 2012). Tidak hanya itu, platform ini juga digunakan untuk mempromosikan permasalahan lingkungan yang kini-berkat semakin mengglobalnya diskursus Artik-juga menjadi isu global (Doods \& Nuttall 2019a).

\section{Kesimpulan}

Lingkar Arktik tidak dapat dipungkiri lagi telah menjadi wilayah yang cukup kompleks dan menjadi cukup prominen di era kontemporer; utamanya jika dikaitkan dengan diskursus sumber daya, energi, dan kemaritiman yang menjadi kontestasi politik di ranah internasional. Mencairnya es di wilayah tersebut menyediakan sebuah peluang baru bagi eksplorasi salah satu cadangan minyak bumi dan gas alam yang mungkin belum terjamah oleh manusia; sehingga juga berujung pada sejumlah sengketa. Tidak hanya itu, fenomena yang disebabkan oleh perubahan iklim ini juga menjadi momentum bagi potensi terbukanya jalur transportasi laut yang secara perhitungan ekonomis dapat memangkas biaya perkapalan transkontiental secara signifikan. Namun, dengan mengutilisasikan landasan normatif Kosmopolitanisme Kritis dan Poskolonial, tulisan ini telah mengupas bahwa paradigma yang berkembang di Lingkar Artik sekarang cenderung terlalu bias pada perhelatan yang state-centric dan high politics semata-sehingga menghiraukan aspek kesejahteraan dan lingkungan yang selama ini turut terjadi pula di Lingkar Artik. Pendekatan Geopolitik Kritis dan Indigenous yang diinduksikan semakin mengafirmasi pula bagaimana hegemoni nation-states membayang-bayangi aktor yang selama ini termarginalkan, 
seperti halnya masyarakat adat yang juga berhak untuk mendapat sorotan yang sama besarnya.

Tulisan ini telah menunjukan bagaimana perjuangan yang dilakukan oleh masyarakat adat, terlebih Suku Inuit, dalam koridor emansipatif dan representatif di Lingkar Arktik. Bayang-bayang nation-states yang juga merupakan kepanjangan dari 'Kolonialisme' di wilayah tersebut telah merebut hak-hak masyarakat adat terhadap 'Homeland' dan identitas kesukuan mereka yang distingtif. Bias yang dimiliki oleh negara bangsa dengan mencitrakan Lingkar Arktik sebagai 'wilayah tidak terjamah' pun semakin mendorong semangat untuk mengeksploitasi. Masyarakat adat Arktik juga berhak untuk memiliki kesempatan untuk mempersepsikan lingkungan Arktik dengan kacamata mereka, yang mana dipengaruhi oleh spiritualisme dan tradisi keadaatan, sehingga membentuk suatu ontologi dan epistemologi tata-kelola tersendiri. Dalam mengaspirasikan hal ini, kini, masyarakat adat melakukan berbagai inisasi selfrepresentation melalui budaya populer dan interaksi antar-budaya yang turut diploriferasi oleh gelombang transformasi dan migrasi global. Di sektor politik, masyarakat adat juga turut aktif dalam perhelatan internasional dan transnasional yang juga didukung oleh tren yang ada dalam norma internasional kontemporer. Pada akhirnya, perubahan sikap dan paradigma global yang sekarang menggaungkan inklusivitas, emansipasi, dan secara garis besar, masyarakat yang lebih Kosmopolit ini lambat-laun akan mengantarkan masyarakat adat mencapai pengakuan dan representasi-meskipun dalam lika-liku bayang-bayang nation-states. 


\section{Daftar Pustaka}

\section{Buku dan Bab dalam Buku}

Brennan, T., 1997. At Home in the World: Cosmopolitanism Now. Cambridge: Havard University Press.

Cohen, S. B., 2015. "Survey in Geopolitics", dalam Geopolitics: The Geography of International Relations. London: Rowman \& Littlefield.

Doods, K. \& Nuttall, M., 2019a. "Arctic Homelands", dalam The Arctic: What Everyone Needs to Know. New York: Oxford University Press USA, pp. 72-120.

. 2019b. "Introduction: One Arctic, Many Arctics", dalam The Arctic: What Everyone Needs to Know. New York: Oxford University Press USA, pp. 1-25.

Flint, C., 2006. Introduction to Geopolitics. New York: Routledge.

Gibson, C., 2016. "Indigenous Geopolitics", dalam Merje Kuus, et. al. (eds.) The Ashgate Research Companion to Critical Geopolitics. London: Routledge, pp. 421-438.

Pelaudeix, C., 2012. "Inuit Governance in a Changing Environment: A Scientific or Political Project?”, dalam Pelaudeix, C., et. al. (eds.) What Holds the Arctic Together? Paris: L'Harmattan, pp. 67-83.

Sowa, F., 2014. "Inuit", dalam Hund, A. (ed.) Antarctica and the Arctic Circle: A Geographic Encyclopedia of the Earth's Polar Regions. Santa Barbara, CA: ABC-CLIO, pp. 390-395.

\section{Artikel Jurnal}

Brunn, J. M. \& Medby, I. A., 2014. "Theorising the Thaw: Geopolitics in a Changing Arctic”, Geography Compass, 8(12):915-929.

Dalby, S., 2008. "Imperialism, Domination, Culture: The Continued Relevance of Critical Geopolitics”, Geopolitics, 13 (3):413-436.

Delanty, G., 2008. "The Cosmopolitan Imagination", Revista CIDOB d'Afers Internacionals, 82/83, 217-230 . 2014. "Not All is Lost in Translation: World Varieties of Cosmopolitanism", Cultural Sociology, 1-18 
Depledge, D. \& Kennedy-Pipe, C., 2018. "The Changing World of the Arctic”, Geography (Sheffield), 103:154-161.

Dittmer, J., et. al., 2011. "Have you Heard the One about the Disappearing Ice? Recasting Arctic Geopolitics", Political Geography, 30: 202-214.

Doods, K., 2010. "Flag Planting and Finger Pointing: The Law of the Sea, the Arctic and the Political Geographies of the Outer Continental Shelf", Political Geography, 29(2):63-73.

Ebinger, C. K. \& Zambetakis, E., 2009. "The Geopolitics of Arctic Melt", International Affairs (Royal Institute of International Affairs 1944), 85 (6):1215-1232.

Go, J., 2012. “Fanon's Postcolonial Cosmopolitanism”, European Journal of Social Theory, 16(2):208-225.

Hommel, D. \& Murphy, A. B., 2013. "Rethinking Geopolitics in an Era of Climate Change", GeoJournal (Dordrecht), 78(3):507-524.

Laruelle, M., 2019. "Postcolonial Polar Cities? New Indigenous and Cosmopolitan Urbanness in the Arctic", Acta Borealia, 36(2): 149-165

O Tuathail, G., 1999. "Understanding critical geopolitics: Geopolitics and risk society", Journal of Strategic Studies, 22 (2-3): 107-124.

Plaut, S., 2012. "'Cooperation is the Story' - The Best Practices of Transnational Indigenous Activism in the North", The International Journal of Human Rights, 16(1): 193-215.

Uimonen, P., 2020. "Decolonizing cosmopolitanism: An anthropological reading of Immanuel Kant and Kwame Nkrumah on the world as one", Critique of Anthropology, 40(1), 81-101.

\section{Laporan dan Publikasi Resmi}

Circum-Arctic Resource Appraisal: Estimates of Undiscovered Oil and Gas North of the Arctic Circle, 2008. Menlo Park: U.S Geological Survey (USGS).

\section{Artikel Daring}

Arctic Centre. t.t. "Arctic Indigenous Peoples", [Daring] Arctic Centre: University of Lapland. Tersedia dalam [https://www.arcticcentre. org/EN/arcticregion/Arctic-Indigenous-Peoples] (diakses pada [27 Mei 2020]). 